\title{
Studies on the effect of storage on viability of wettable powder (WP) formulations of the entomopathogenic fungi Metarhizium anisopliae (Metschinikoff) Sorokin
}

S.D. Patil* and R.S. Jadhav ${ }^{1}$

Agricultural Research Station, Niphad, Nasik (M.S.) India

${ }^{1}$ Department of Entomology, AICRP on Soybean, Vasantrao Naik Marathwada Krishi Vidyapeeth, Parbhani (M.S.) India

\section{ARITCLE INFO}

Received : 03.12 .2018

Revised : 16.03 .2019

Accepted : 22.03.2019

\section{KEY WORDS :}

Metarhizium anisopliae, Adjuvants, Formulation, Wettable powder, Sunflower oil, Honey, Carboxymethyl cellulose, Colony forming unit
*Corresponding author:

Email : saurushrutu@gmail.com

\begin{abstract}
Studies on the effect of storage of developed Metarhizium anisopliae (Metschnikoff) Sorokin 5 per cent WP formulation $\mathrm{A} 1\left(\mathrm{M}_{30} \mathrm{~S}_{1 / 1} \mathrm{C}_{1 / 2}\right)$ and $\mathrm{B} 1\left(\mathrm{M}_{30} \mathrm{~S}_{1 / 1} \mathrm{H}_{1 / 1}\right)$ (comprising adjuvants, fungus and kaolinite) and M.anisopliae alone in kaolinite (control) on viability of the fungus are undertaken.At $10 \mathrm{DAI}$, surface coverage by the fungus varied from 100 to $45.0,100$ to 46.67 and 100 to 0.0 per cent in formulation A1, B1 and control, respectively, when stored for 0 to 300 days. The samples stored upto 150 days showed cent per cent surface coverage in formulation A1 and B1 except control. Significantly higher biomass ( 9.10 to $10.03 \mathrm{~g} / 40 \mathrm{ml}$ medium) was produced in samples of formulation $\mathrm{A} 1$ and $\mathrm{B} 1$ (8.77 to $10.07 \mathrm{~g}$ ) stored upto 210 days as compared to that $(3.40 \mathrm{~g})$ in formulation $\mathrm{A} 1$ and $\mathrm{B} 1(3.70 \mathrm{~g})$ stored for 300 days. The biomass in control was $6.27 \mathrm{~g}$ in fresh sample against no biomass in sample stored for 300 days. The viability varied from 31.33 to $5.33 \times 10^{8}, 30.67$ to $6.33 \times 10^{8}$ and 30.67 to $0.0 \times 10^{8} \mathrm{cfu} / \mathrm{ml}$ in formulation $\mathrm{A} 1, \mathrm{~B} 1$ and control, respectively, from 0 to 300 days storage. Considering surface coverage (\%), biomass produced and viability (cfu/g) the $M$. anisopliae 5 pe cent WP formulation A1, B1 and control could be stored upto 10, 10 and 6 months, respectively for the minimum cfu count of $1 \times 10^{8} / \mathrm{g}$ for WP formulations as per norms.
\end{abstract}

How to view point the article : Patil, S.D. and Jadhav, R.S. (2019). Studies on the effect of storage on viability of wettable powder (WP) formulations of the entomopathogenic fungi Metarhizium anisopliae (Metschinikoff) Sorokin . Internat. J. Plant Protec., 12(1) : 72-76, DOI : 10.15740/HAS/IJPP/12.1/72-76, Copyright@ 2019: Hind Agri-Horticultural Society. 